\title{
Regulation of Lipoprotein Lipase in Primary Cultures of Isolated Human Adipocytes
}

\author{
Philip A. Kern, Stephen Marshall, and Robert H. Eckel
}

Department of Medicine, Division of Endocrinology, University of Colorado Health Sciences Center, Denver, Colorado 80262

\begin{abstract}
To study the regulation of adipose tissue lipoprotein lipase (LPL) in human adipocytes, omental adipose tissue was obtained from healthy subjects and digested in collagenase. The isolated adipocytes thus obtained were suspended in Medium 199 and cultured at $37^{\circ} \mathrm{C}$. Cell viability was demonstrated in adipocytes cultured for up to $72 \mathrm{~h}$ by constancy of cell number, cell size, trypan-blue exclusion, and specific ${ }^{125}$ I-insulin binding. In addition, chloroquine induced an increase in cell-associated ${ }^{125} \mathrm{I}$-insulin at 24,48 , and $72 \mathrm{~h}$ after preparation. Thus, isolated adipocytes retained their ability to bind, internalize, and degrade insulin.

LPL was measured as activity secreted into the culture medium (CM), released from cells by heparin (HR), and extracted from cell digests. A broad range of heparin concentrations produced a prompt release of LPL from a rapidly replenishable pool of cellular activity. When cells were cultured in medium containing $10 \%$ fetal bovine serum, there was a marked stimulation of $\mathrm{CM}$ and $\mathrm{HR}$. The secretory response to serum (CM) correlated strongly with HR $24 \mathrm{~h}$ after preparation $\left(r_{s}=0.731, P<0.001\right)$. In addition, $H R$ was found to correlate logarithmically and inversely with body mass index ( $r$ $=-0.731, P<0.001)$. Insulin, at $400 \mathrm{ng} / \mathrm{ml}$ only, increased HR by $36 \pm 10 \%$, an effect simulated by lower concentrations of insulin-like growth factor-1 (IGF 1 ).

Thus, LPL is produced and regulated in isolated human adipocytes. The degree of adiposity and serum are important regulators of $\mathrm{HR}$ activity, whereas insulin is stimulatory only at a pharmacologic concentration. This effect of insulin may be mediated through the IGF 1 receptor. Isolated human adipocytes represent a novel and useful system for the study of LPL and lipid metabolism as well as for other aspects of adipocyte biology.
\end{abstract}

\section{Introduction}

Adipose tissue lipoprotein lipase (LPL) ${ }^{1}$ is the enzyme responsible for the hydrolysis of the triglyceride core of chylomicrons

This work was presented in part at the 42nd and 43rd Annual Meetings of the American Diabetes Association, San Francisco, California (1982) and San Antonio, Texas (1983).

Dr. Marshall is currently at the University of California, San Diego. Address reprint requests to Dr. Kern, Division of Endocrinology, Cedars-Sinai Medical Center, Room 1735, 8700 Beverly Blvd., Los Angeles, California 90048.

Received for publication 7 November 1983 and in revised form 31 August 1984.

1. Abbreviations used in this paper: $\mathrm{CM}$, culture medium activity; EXT, extractable activity; HR, heparin releasable activity; IGF $_{1}$, insulinlike growth factor-1; LPL, lipoprotein lipase.

J. Clin. Invest.

(C) The American Society for Clinical Investigation, Inc.

$0021-9738 / 85 / 01 / 0189 / 10 \quad \$ 1.00$

Volume 75, January 1985, 199-208 and very low density lipoproteins into monoacylglycerol and free fatty acids (1). LPL deficiency may be involved in the hyperlipidemia seen in numerous disease states, such as poorly controlled diabetes mellitus $(2,3)$, chronic renal failure (4), and hypothyroidism $(5,6)$. Increases in adipose tissue LPL after weight loss suggest a role for this enzyme in weight maintenance (7). In addition, LPL-mediated triglyceride hydrolysis appears to be important in the generation of $\mathrm{HDL}_{2}$ (8), the subfraction of high density lipoprotein that may protect against atherosclerosis (9).

LPL is synthesized in the adipocyte, secreted into the interstitial space, and transported to the capillary endothelium, where it is bound to glycosaminoglycans (10). Since the regulation of this enzyme may take place at numerous sites in LPL processing, studies in vivo or with whole adipose tissue in vitro have not been able to provide insight into LPL regulation at the level of the adipocyte. Thus, a system has been needed where the effects of hormones and other regulators can be directly assessed on adipose cells in vitro.

LPL has been measured in cultured 3T3-L1 cells (11) and in preadipocytes isolated from the stromal-vascular fraction of mouse (12) and rat (13) adipose tissue. These cultures, however, contain preadipocytes and other cell types in various stages of adipocyte differentiation and produce variable amounts of LPL $(14,15)$. Although isolated rat adipocytes produce LPL (16), studies of regulation in these buffer-suspended cells have been limited due to short-term viability. Methodology has recently been developed to study the regulation of LPL in isolated rat adipocytes (17), which remain viable in culture for several days $(17,18)$. However, conclusions drawn from studies using rat adipocytes may not relate to human pathophysiology. Thus, a system to study LPL in adipocytes obtained from human adipose tissue biopsies would be desirable.

In this report, we describe the preparation of human adipocytes from a collagenase digestion of omental adipose tissue, and their maintenance in a tissue culture environment for several days. These cells produce and secrete abundant LPL activity, which is regulated by factors such as serum, degree of adiposity, insulin, and insulin-like growth factor-1 $\left(\mathrm{IGF}_{1}\right)$.

\section{Methods}

Preparation of isolated adipocytes. After patients gave informed consent, $\sim 10 \mathrm{~g}$ of omental adipose tissue was obtained from 45 healthy subjects (39 females, 6 males) under the age of 50 undergoing elective surgery for nonmalignant conditions. Patients were excluded if there was any evidence of chronic disease, and LPL data were not obtained if the patient was taking any medications known to affect lipid metabolism (such as insulin, oral contraceptives, or glucocorticoids). The mean $( \pm$ SE) percentage of ideal body weight (19) of the subjects was $108 \pm 1.9 \%$ (range, $90-139 \%, n=45$ ). The nature of the surgical procedures varied but were all elective operations such as hysterectomies, ovarian cystectomies, and cholecystectomies. Patients routinely fasted for 8-14 h before surgery and were intravenously hydrated during surgery with lactated Ringer's solution containing 5\% glucose.

Omental adipose tissue was excised and immediately placed into 
sterile, iced phosphate-buffered saline containing $1.0 \mathrm{mM} \mathrm{CaCl}_{2}$ and processed within $1 \mathrm{~h}$. By the method of Rodbell (20) the tissue was divided into 1-2 $\mathrm{g}$ pieces, minced, and transferred to a polypropylene flask containing $7 \mathrm{ml}$ of collagenase II $(2 \mathrm{mg} / \mathrm{ml}$; Worthington Biochemical Corp., Freehold, NJ) in Krebs Ringer bicarbonate buffer with $3 \mathrm{mM}$ glucose and $4 \%$ bovine serum albumin. The tissue was digested at $37^{\circ} \mathrm{C}$ for $60-90 \mathrm{~min}$ in a rotary water bath at $140 \mathrm{rpm}$. The suspension was then passed through a $250-\mu \mathrm{m}$ pore nylon mesh (Small Parts, Inc., Miami, FL) to remove undigested pieces, and Medium 199 (Gibco Laboratories, Grand Island, NY), containing 10\% heat-inactivated whole fetal bovine serum (Reheis Co., Inc., New York) and penicillin/streptomycin $(100 \mathrm{U} / \mathrm{ml}$ and $100 \mu \mathrm{g} / \mathrm{ml}$, respectively; Gibco Laboratories) were added to the filtrate. The adipocytes were allowed to float above the heavier stromal-vascular elements, which remained in the medium below the adipocytes. This infranatant was then removed, and the adipocytes were washed twice in serum-containing medium and twice in serum-free medium. A 75- $\mu$ l aliquot of concentrated cell suspension $\left(1.17 \pm 0.10 \times 10^{5}\right.$ cells, mean \pm SEM, $\left.n=40\right)$ was added to $0.75 \mathrm{ml}$ Medium 199, in the presence or absence of serum in sterile $12 \times 75 \mathrm{~mm}$ polypropylene tubes. The cells were then incubated at $37^{\circ} \mathrm{C}$ in a humid $95 \%$ air-5\% $\mathrm{CO}_{2}$ environment. In some experiments, cells were cultured in Medium 199 containing $10 \%$ dialyzed fetal bovine serum. This serum was dialyzed at $4^{\circ} \mathrm{C}$ against $0.15 \mathrm{M} \mathrm{NaCl}$ using a 3,500-mol wt membrane with two dialysate changes over $24 \mathrm{~h}$.

Insulin binding. Specific ${ }^{125}$ I-insulin binding was measured by a modification of the technique of Marshall and Olefsky (21). After incubation at $37^{\circ} \mathrm{C}$ in Medium 199 , as described above, $\sim 1.0 \times 10^{5}$ cells were washed and incubated in $1.0 \mathrm{ml}$ of minimal essential medium (Gibco Laboratories) containing $25 \mathrm{mM}$ 4-(2-hydroxyethyl)1-piperazineethanesulfonic acid (Hepes, pH 7.8), 1\% bovine serum albumin, and 5\% fetal bovine serum (Reheis Co., Inc.). ${ }^{125} \mathrm{I}$-insulin $(0.3 \mathrm{ng})$ was then added in the absence or presence of a large excess $(50 \mu \mathrm{g})$ of unlabeled porcine sodium insulin (a gift of Dr. Ron Chance, Eli Lilly \& Co., Indianapolis, IN). To assess intracellular insulin processing, experiments were performed in the presence of $50 \mu \mathrm{M}$ chloroquine (Sigma Chemical Co., St. Louis MO), an agent that blocks intracellular insulin degradation and causes an accumulation of intact ${ }^{125}$ I-insulin within cells (21). Termination of the binding reaction was carried out by rapidly centrifuging triplicate $200-\mu$ l aliquots of cell suspension in microtubes containing $100 \mu \mathrm{l}$ of silicone oil. The adipocytes were thus separated from the medium, and specific cell associated ${ }^{125} \mathrm{I}$-insulin was determined.

Cell size. An aliquot of adipocyte suspension was washed and sized microscopically by the use of methylene blue (22). In some experiments, sizing was performed with cells suspended in trypan blue. Comparisons between trypan blue and methylene blue staining revealed no difference in cell size between the two techniques.

Cell counting. Adipocyte number was determined according to a modification of method III of Hirsch and Gallian (23). Cells were washed and fixed in $2 \%$ osmium tetroxide in $0.05 \mathrm{M}$ collidine buffer (made isotonic with saline) for $24 \mathrm{~h}$ at $37^{\circ} \mathrm{C}$, then taken up in a known volume of $0.15 \mathrm{M} \mathrm{NaCl}$ for counting in a model ZB Coulter Counter with a $400-\mu \mathrm{m}$ aperature (Coulter Electronics Inc., Hialeah, FL).

Trypan blue exclusion. By a modification of the technique used for fibroblasts (24), cells were washed with phosphate-buffered saline and incubated with $0.4 \%$ trypan blue in $0.9 \% \mathrm{NaCl}$ for $15 \mathrm{~min}$ at $37^{\circ} \mathrm{C}$.

Adipose tissue LPL. LPL activity was measured against a [1$\left.{ }^{14} \mathrm{C}\right]$ triolein substrate by a modification of a method used previously for cells from the stromal vascular fraction of adipose tissue (25). Three compartments of adipocyte LPL activity were measured: (a) activity secreted into the culture medium $(\mathrm{CM}),(b)$ activity released by heparin (HR), and (c) cellular activity extractable in deoxycholate and detergent (EXT), by a modification of the method of Iverius (26). For the measurement of $\mathrm{CM}, 150 \mu \mathrm{l}$ of medium bathing the cells was incubated with $50 \mu \mathrm{l}$ of substrate (described below) for $45 \mathrm{~min}$ at $37^{\circ} \mathrm{C}$. The reaction was then terminated by the addition of $3.25 \mathrm{ml}$ of the extraction mixture of Belfrage and Vaughn (27), and released fatty acids were extracted for $10 \mathrm{~min}$ on an Eberbach Shaker (Eberbach Corp., Ann Arbor, MI). After centrifugation at $2,000 \mathrm{~g}$ for $20 \mathrm{~min}$, $0.5 \mathrm{ml}$ of the upper phase was placed in $3.0 \mathrm{ml}$ Aquasol (New England Nuclear, Boston, MA) and counted in a liquid scintillation counter. For HR, the cells were washed twice in Krebs Ringer phosphate buffer and incubated for $45 \mathrm{~min}$ at $37^{\circ} \mathrm{C}$ in $0.4 \mathrm{ml}$ buffer containing 13.5 $\mu \mathrm{g} / \mathrm{ml}$ heparin (beef lung; Upjohn Co., Kalamazoo, MI). An aliquot of buffer, containing released LPL activity, was then assayed as described above. To measure EXT, the previously heparin-released cells were transferred to a microhomogenizer, washed twice, and disrupted in the presence of $0.2 \mathrm{ml}$ of solution containing $0.2 \mathrm{M}$ Tris (pH 8.5), 0.73\% sucrose, 1.0\% albumin, 0.5\% deoxycholate (Sigma Chemical Co.), $0.02 \%$ Nonidet $\mathbf{P}_{\mathbf{4 0}}$ (neutral detergent; Sigma Chemical Co.), and $125 \mu \mathrm{g} / \mathrm{ml}$ heparin. After the addition of $0.5 \mathrm{ml}$ of Trissucrose-albumin-buffer, the suspension was centrifuged at $2,000 \mathrm{~g}$ for $30 \mathrm{~min}$, and the middle layer, containing solubilized LPL activity, was assayed as described above.

The substrate used in the LPL assay was prepared with $5 \mathrm{mg}$ of unlabeled triolein (Sigma Chemical Co.), $4 \mu \mathrm{Ci}\left[1-{ }^{14} \mathrm{C}\right]$ triolein (Amersham Corp., Arlington Heights, IL) and $0.24 \mathrm{mg}$ phosphatidylcholine (Applied Science Div., Milton Roy Co., State College, PA). After the addition of a mixture of $10 \%$ fatty acid-poor albumin (Miles Laboratories Inc., Elkhart, IN), normal human serum, $2 \mathrm{M}$ Tris- $\mathrm{HCl}$ buffer ( $\mathrm{pH}$ 8.2), and distilled water in a ratio of 4:3:5:9.5, the substrate was emulsified by $100 \mathrm{~s}$ of sonication ( $10 \mathrm{~s}$ on, $10 \mathrm{~s}$ off, for 10 cycles) at $4^{\circ} \mathrm{C}$ with a cell disrupter 200 model (Heat Systems-Ultrasonics, Inc., Plainview, NY).

$I G F_{1}$. Two preparations of human IGF $_{1}$ were used. Three experiments were carried out with IGF, (batch number 16SPII) that was highly purified from a Cohn fraction of plasma by Dr. R. E. Humbel (Biochemisches Institut der Universität Zürich, Switzerland) (28), and was a generous gift of Dr. Ted Ciaraldi (University of California, San Diego, La Jolla, CA). This preparation of IGF, migrated as a single band upon polyacrylamide gel electrophoresis (28). Further experiments were performed with an IGF 1 analogue (preparation IT-AC3) prepared by means of recombinant DNA technology by AMGen Development, Inc. (Boulder, Colorado) (29). This peptide has a threonine-for-methionine substitution at position 59 but is otherwise homologous with plasma purified $I_{G F}$. In recent studies characterizing this product, receptor binding, biological activity, and immunoactivity were found to be similar to those of plasma purified IGF $_{1}(29)$.

Statistics. All data are expressed as the mean \pm SE with the number of experiments given. Most data were analyzed nonparametrically by the Wilcoxon matched-paired signed-ranks test or the Spearman rank correlation coefficient test. The linear regression for the logarithmic transformation (see Fig. 9) was performed parametrically.

\section{Results}

The primary cultures of isolated adipocytes formed a homogeneous layer on the surface of the culture medium. To verify that only negligible cell breakage was occurring, cell number was determined on aliquots of adipocytes cultured for up to $72 \mathrm{~h}$. As shown in Table I, no significant change in adipocyte number occurred. Average cell size also remained constant in cultured adipocytes, suggesting that there was no selective breakage of the larger adipocytes. Further evidence of cell membrane integrity included consistently low trypan-blue uptake (Table I).

To assess further the viability of cultured adipocytes, the ability of these cells to bind and internalize insulin was measured. After cells were cultured for up to $72 \mathrm{~h}$, cellassociated ${ }^{125} \mathrm{I}$-insulin was measured after a 2-h incubation at $37^{\circ} \mathrm{C}$ in the presence or absence of $50 \mu \mathrm{M}$ chloroquine. Chloroquine has previously been shown to increase adipocyte- 
Table I. Cell Number, Cell Size, and Trypan Blue Exclusion in Cultured Human Adipocytes

\begin{tabular}{llll}
\hline Time & Cell number* & Cell size* & $\begin{array}{l}\text { Trypan blue } \\
\text { exclusion* }\end{array}$ \\
\hline$h$ & \% time $0(n)$ & \% time $0(n)$ & $\begin{array}{l}\text { \% dye-positive } \\
\text { cells }(n)\end{array}$ \\
0 & $100 \quad(7)$ & $100(4)$ & $3.2 \pm 1.7(7)$ \\
24 & $100 \pm 21(7)$ & $99 \pm 5(4)$ & $0.7 \pm 0.2(3)$ \\
48 & $108 \pm 14(7)$ & $92 \pm 7(3)$ & $1.0 \pm 0.6(3)$ \\
72 & $109 \pm 20(7)$ & $99 \pm 8(3)$ & $1.5 \pm 0.9(3)$
\end{tabular}

* Mean \pm SE.

associated ${ }^{125} \mathrm{I}$-insulin by inhibiting intracellular insulin degradation and thus trapping internalized insulin within the cell. As shown in Fig. 1, insulin binding in the absence of chloroquine remained constant in cells cultured for up to $72 \mathrm{~h}$. Chloroquine, however, induced increases in cell-associated radioactivity of 51,65 , and $36 \%$ at 24,48 , and $72 \mathrm{~h}$ after preparation, respectively. This chloroquine effect was consistently present in cultured cells and was of greater magnitude than the minimal effect seen in freshly prepared cells.

LPL was measured as activity secreted into the culture medium (CM), released from cells with $13.5 \mu \mathrm{g} / \mathrm{ml}$ heparin (HR), and extracted from the heparin-released cells by deoxycholate and detergent (EXT). To demonstrate that HR and EXT represent two different components of cellular LPL activity, total cell activity of washed adipocytes was determined and compared with the sum of HR and EXT in parallel cultures. Total cell activity was determined in nonheparinreleased cells by the extraction technique (cell disruption in neutral detergent and deoxycholate) described in Methods. As shown in Table II, the sum of HR and EXT consistently and accurately reflected the measured total cell activity, thus dem-

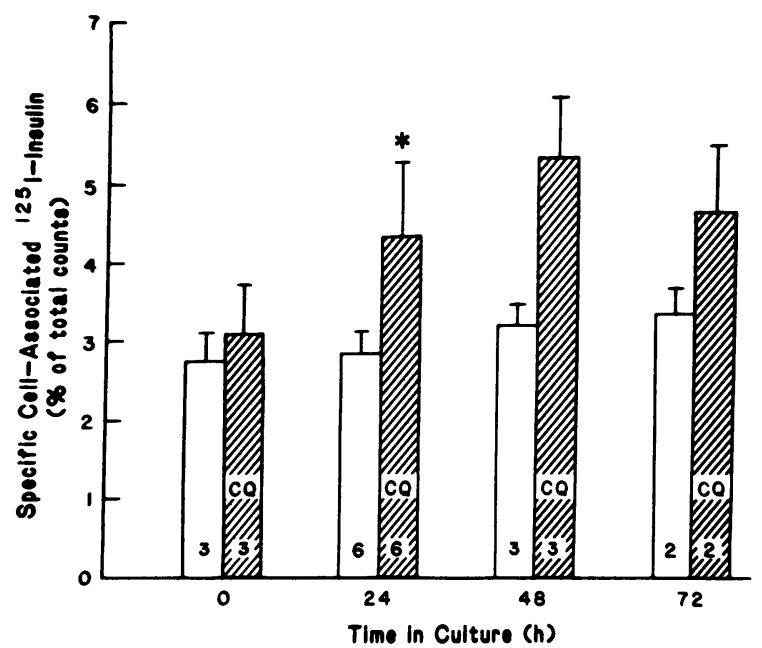

Figure 1. Insulin binding in the presence or absence of chloroquine (CQ). After culturing of cells for the indicated times, $0.3 \mathrm{ng}$ of ${ }^{125} \mathrm{I}$ insulin was added and cells were incubated at $37^{\circ} \mathrm{C}$ for $2 \mathrm{~h}$ in the presence or absence of $50 \mu \mathrm{M} \mathrm{CQ}$. Nonspecific binding was determined for each point by a duplicate tube of cells to which $50 \mu \mathrm{g}$ of unlabeled insulin was added. Cell-associated activity is expressed as percentage of total ${ }^{125} \mathrm{I}$-insulin added per $2 \times 10^{5}$ cells, after subtraction of nonspecific binding. ${ }^{*} P=0.05$.
Table II. Division of Cellular LPL Activity into HR and EXT

\begin{tabular}{lllll}
\hline & & & \multicolumn{2}{c}{ Total cell activity } \\
\cline { 4 - 5 } Experiment & HR & EXT & Calculated* & Measured‡ \\
\hline 1 & 1.63 & 1.50 & 3.13 & 3.23 \\
2 & 2.68 & 1.51 & 4.19 & 4.17 \\
3 & 2.85 & 1.62 & 4.47 & 4.35
\end{tabular}

Activity is expressed as nanoequivalents of free fatty acid released per minute per $10^{6}$ cells.

* Sum of HR and EXT.

$¥$ Nonheparin-released cells were disrupted in the presence of neutral detergent and deoxycholate. Solubilized LPL was then assayed (see Methods).

onstrating the additive nature of these two components of cellular activity.

To examine the time course of LPL production by adipocytes, CM, HR, and EXT were measured after various times in culture. In cells incubated in Medium 199 alone, CM remained very low, whereas $H R$ increased progressively, reaching a plateau between 10 and $24 \mathrm{~h}$, then diminishing somewhat at 48 and $72 \mathrm{~h}$ (Fig. 2). Cultures that were incubated in medium containing $10 \%$ fetal bovine serum similarly showed a progressive increase in HR but also demonstrated a rapid rise in CM (Fig. 2). EXT remained relatively stable over $72 \mathrm{~h}$ and was not markedly influenced by the addition of serum. Because CM and HR were at a maximum at $24 \mathrm{~h}$, data on LPL regulation were obtained at this time. Fig. 3 illustrates the effects of $10 \%$ serum in paired experiments of adipocytes cultured for $24 \mathrm{~h}$. The mean ( $\pm \mathrm{SE}$ ) increases in CM and HR were $1.66 \pm 0.35$ and $1.72 \pm 0.32 \mathrm{neq} / \mathrm{min}$ per $10^{6}$ cells, respec-
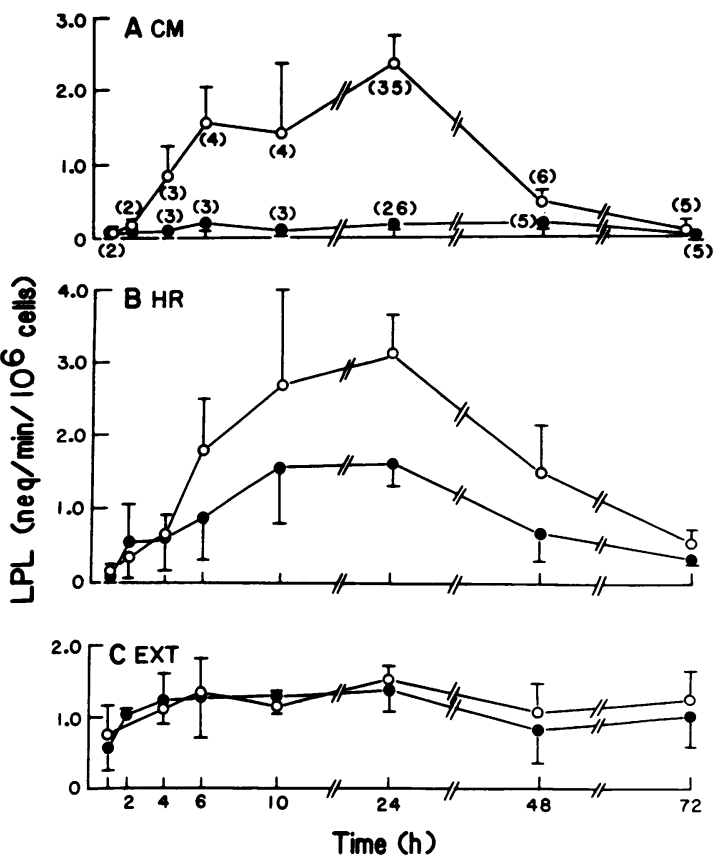

Figure 2. Time course of LPL activity. LPL was measured as $(A)$ CM, $(B) \mathrm{HR}$, and $(C)$ EXT (see Methods). Cells were cultured in Medium 199 in the absence (๑) or presence (O) of $10 \%$ fetal bovine serum (mean $\pm \mathrm{SE})$. 


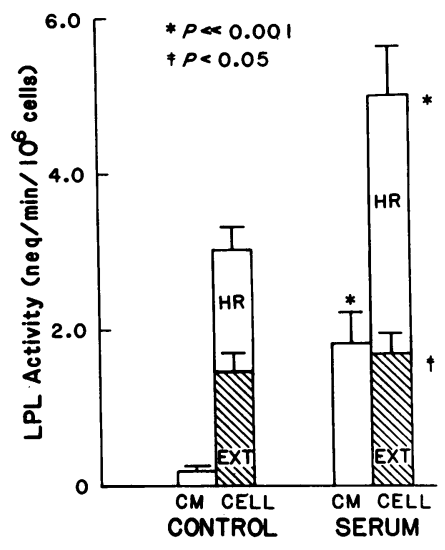

Figure 3. Effects of serum on LPL. In paired experiments, adipocytes were incubated for $24 \mathrm{~h}$ in Medium 199 in the absence (control) or presence (serum) of $10 \%$ fetal bovine serum. LPL was then measured as cellular activity and as $\mathrm{CM}$. Activity in the cell was assayed as HR and EXT activity (mean \pm SE).

tively ( $n=25, P \ll 0.001$ ). In contrast, only a slight, albeit statistically significant, increase in EXT was observed in response to serum $\left(0.24 \pm 0.13 \mathrm{neq} / \mathrm{min}\right.$ per $10^{6}$ cells, $n=21, P$ $<0.05$ ). This effect on $C M$ and $H R$ was unchanged when dialyzed serum was used.

As illustrated above, CM was very low, and often undetectable, in the absence of serum. This could be due to enzyme instability in the absence of serum. Alternatively, serum may be required to induce LPL secretion from adipocytes. To determine whether this was due to a stabilization of the enzyme by serum, the biological half-life of LPL at $37^{\circ} \mathrm{C}$ was characterized. As shown in Fig. 4, the half-life of CM (in the presence of serum) was $66 \mathrm{~min}$. Because $\mathrm{CM}$ in the absence of serum was so low, the half-life of this form of LPL could not be determined. Nevertheless, when $\mathrm{CM}$ was removed from these cells and immediately incubated with serum, there was no increment in LPL activity. To assess further any direct effect of serum on LPL, the half-life of HR (from cells incubated without serum) was determined in both the presence of absence of added serum (Fig. 4). Without serum, the halflife of HR was $113 \mathrm{~min}$, whereas with added serum the halflife of HR was $135 \mathrm{~min}$. This difference between the half-lives of $H R$ and $H R$ with added serum was inconsistent and not statistically significant. Thus, the half-life of $\mathrm{HR}$ was longer

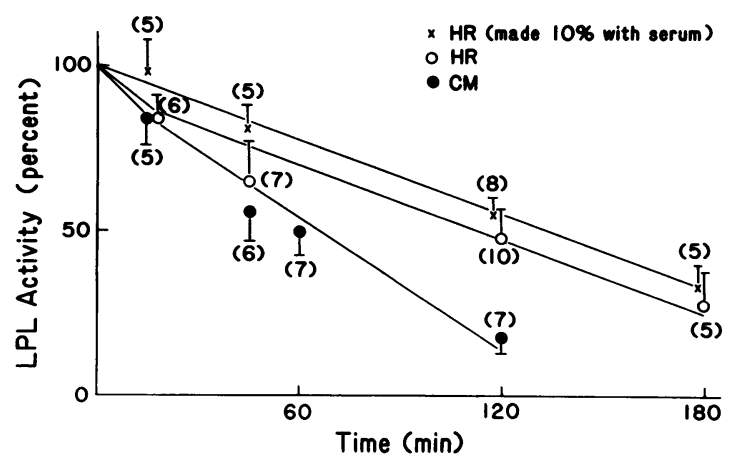

Figure 4. Half-life of LPL activity. After cells were incubated overnight in serum-containing medium, the $\mathrm{CM}$ was separated from cells and placed at $37^{\circ} \mathrm{C}$, and $\mathrm{LPL}$ activity was measured at the times indicated. For the half-life of $\mathrm{HR}$, cells were cultured overnight in serum-free medium. Activity was then released into buffer by 13.5 $\mu \mathrm{g} / \mathrm{ml}$ heparin for $45 \mathrm{~min}$ at $37^{\circ} \mathrm{C}$. The buffer was then separated from the cells and placed at $37^{\circ} \mathrm{C}$ with either buffer or serum added in a $1 / 10(\mathrm{vol} / \mathrm{vol})$ ratio. Data are expressed as percentage of initial activity. than that of CM, although the addition of serum to HR did not prolong the half-life further.

The release of LPL activity by heparin was characterized in cells cultured for $24 \mathrm{~h}$. The addition of heparin in concentrations of 1.3 to $130 \mu \mathrm{g} / \mathrm{ml}$ at $37^{\circ} \mathrm{C}$ produced a prompt release of LPL into the medium, which reached a maximum within $15 \mathrm{~min}$ (Fig. 5). This maximal level of LPL was sustained in cells exposed to heparin for up to $180 \mathrm{~min}$. As demonstrated in Fig. 4, the half-life of HR when separated from cells was $135 \mathrm{~min}$. Thus, when cells were exposed to heparin, the released LPL maintained a steady state despite the finite half-life of the enzyme in a cell-free system. This suggests that these isolated adipocytes were able to continuously produce and release new enzyme while exposed to heparin.

To determine whether heparin could deplete cells of this pool of cellular activity, cells that had been previously exposed to heparin for 30,60 , and $120 \mathrm{~min}$ were washed, suspended in buffer, and then reexposed to $13 \mu \mathrm{g} / \mathrm{ml}$ of heparin for 45 min at $37^{\circ} \mathrm{C}$. Despite the previous exposure to heparin, the second addition of heparin resulted in the release of additional LPL activity (Fig. 6). Although this second response was $~ 50 \%$ less than the initial heparin release, heparin was clearly unable to deplete the cells of HR activity. To determine whether this residual HR was simply due to the use of a submaximal dose of heparin in the first heparin release, the dose-response relationship between heparin concentration and LPL release was studied. As shown in Fig. 7, a broad range of heparin concentrations was found to release equivalent amounts of LPL, and the heparin concentrations used in Fig. 5 (1.3 to $130 \mu \mathrm{g} / \mathrm{ml}$ ) released maximal amounts of LPL. Thus, heparin failed to deplete adipocytes of $H R$, suggesting that $H R$ represents a rapidly replenishable pool of enzyme activity.

Although CM at $24 \mathrm{~h}$ (in the presence of serum) had reached a steady state, the amount of secreted activity present in $\mathrm{CM}$ varied considerably among primary cultures. To ascertain whether cellular LPL in part determined secreted LPL, paired experiments were conducted with adipocytes cultured for $24 \mathrm{~h}$ in the presence and absence of serum. As shown in Fig. 8, serum-stimulated CM correlated positively with control $\mathrm{HR}$ at $24 \mathrm{~h}\left(r_{\mathrm{s}}=0.731, n=23, P<0.001\right)$. In addition, the two components of cellular activity, $\mathrm{HR}$ and EXT, correlated with each other at $24 \mathrm{~h}\left(r_{\mathrm{s}}=0.501, n=22, P<0.05\right)$. In contrast, there was no significant relationship between serumstimulated CM and EXT $\left(r_{\mathrm{s}}=0.355, P, \mathrm{NS}\right)$. Thus, HR

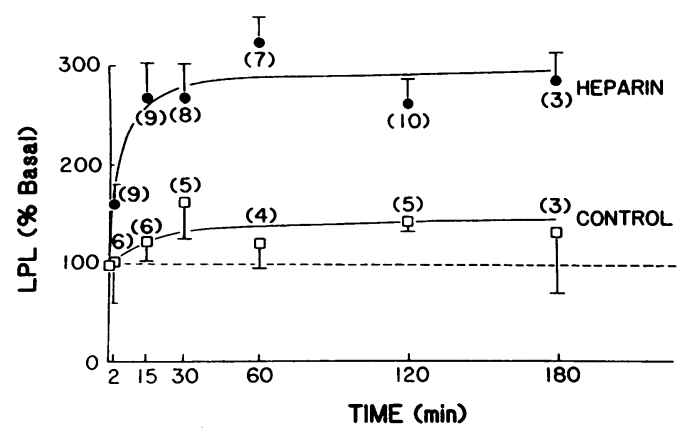

Figure 5. Heparin release of LPL. After incubation of adipocytes for $24 \mathrm{~h}$ in Medium 199 containing $10 \%$ serum, heparin (1.3 to $130 \mu \mathrm{g} /$ $\mathrm{ml}$ ) was added to the culture medium, which was then assayed for LPL. Data for both heparin-treated and control cells are expressed as percentage of activity at time 0 (mean \pm SE). 


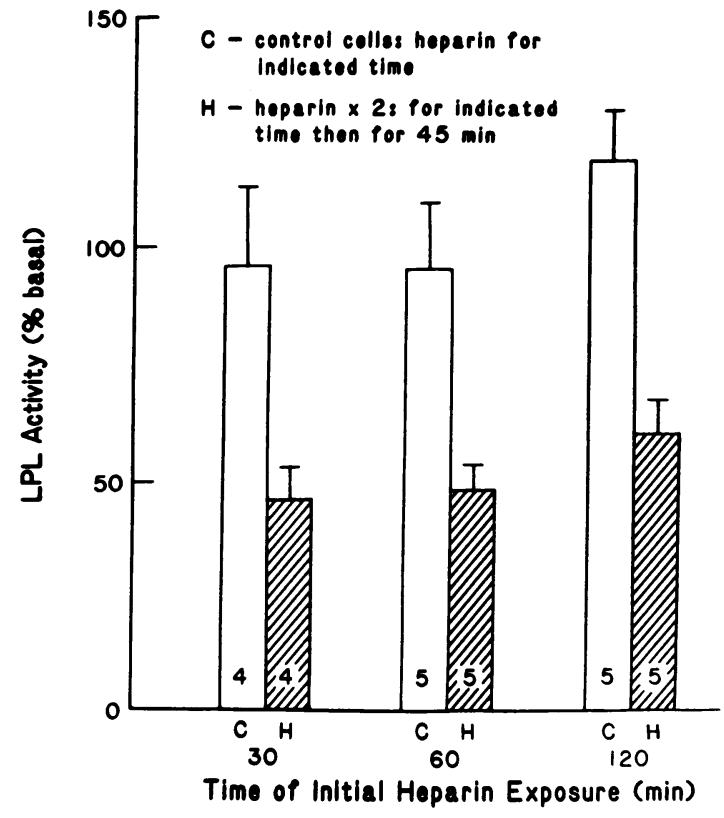

Figure 6. Inability of heparin to deplete adipocytes of heparin releasable activity. Cells that had been previously exposed to heparin for 30,60 , and 120 min were promptly washed and suspended in Krebs Ringer phosphate. Heparin $(13.5 \mu \mathrm{g} / \mathrm{ml})$ was again added and cells were incubated at $37^{\circ} \mathrm{C}$ for $45 \mathrm{~min}$. LPL released into the Krebs Ringer phosphate buffer was then assayed. Control cells had a single exposure to heparin. LPL released from both control cells and cells exposed to heparin twice was expressed as percentage of control cells at time 0 (mean \pm SE).

represented the component of cellular LPL that best predicted the ability of serum to stimulate enzyme secretion.

As illustrated in Fig. 8, HR at $24 \mathrm{~h}$ also varied among individual subjects. Therefore, various factors were examined to determine their effect on HR. When body mass index (weight/height ${ }^{2}$ ) was plotted as a function of $\mathrm{HR}$ at $24 \mathrm{~h}, \mathrm{a}$ curvilinear relationship was obtained (Fig. $9 \mathrm{~A}$ ). A logarithmic plot of these data produced the highly significant inverse linear relationship shown in Fig. $9 \mathrm{~B}$. Although fat cell volume correlated significantly with body mass index $(r=0.775, n$ $=35, P \ll 0.001$ ), there was only a weak relationship between fat cell volume and $\log \mathrm{HR}$ at $24 \mathrm{~h}(r=-0.432, n=22, P$ $=0.05)$. CM and EXT did not correlate significantly with any index of adiposity or with fat cell size. Thus, the degree of subject adiposity played a role in determining steady-state adipocyte HR.

Because it has been suggested to be an important regulator of LPL, insulin was added to cultured adipocytes at the time of preparation over a broad range of concentrations. As shown in Fig. $10 A, 400 \mathrm{ng} / \mathrm{ml}$ of insulin produced a mean increase in HR of $0.50 \pm 0.14 \mathrm{neq} / \mathrm{min}$ per $10^{6}$ cells $(36 \pm 10 \%, n=22$, $P<0.001)$ above non-insulin-treated controls. In addition, this concentration of insulin increased EXT by $0.31 \pm 0.13$ neq $/ \mathrm{min}$ per $10^{6}$ cells $(28 \pm 12 \%, n=21, P<0.01)$. Although $400 \mathrm{ng} / \mathrm{ml}$ of insulin consistently increased HR, the magnitude of this insulin effect varied. As shown in Fig. $10 \mathrm{~B}$, the increase in $\mathrm{HR}$ with $400 \mathrm{ng} / \mathrm{ml}$ of insulin correlated directly with control HR at $24 \mathrm{~h}\left(r_{\mathrm{s}}=0.594, P<0.01\right)$. In contrast, insulin concentrations of 1,4 , and $40 \mathrm{ng} / \mathrm{ml}$ had no effect on either HR or EXT, nor did $400 \mathrm{ng} / \mathrm{ml}$ of insulin have any effect on LPL when added to cells cultured in $10 \%$ serum. Thus, only high concentrations of insulin stimulated cellular LPL, and this effect on HR was greatest in cultures with a high basal HR.

High concentrations of insulin have previously been shown to cross-react with $\operatorname{IGF}_{1}$ receptors $(30,31)$. Because the increases in adipocyte LPL occurred only at $400 \mathrm{ng} / \mathrm{ml}$ of insulin, these effects may have been mediated through the $I_{G} F_{1}$ receptor. To examine this question, experiments were conducted in which adipocytes were cultured with insulin $(400 \mathrm{ng} / \mathrm{ml})$ as well as with a spectrum of concentrations of IGF $_{1}$ (ranging from 0.1 to $500 \mathrm{ng} / \mathrm{ml}$ ). As shown in Fig. 11, IGF produced $_{1}$ a dose-related increase in HR that was statistically significant at concentrations of 10,50 , and $500 \mathrm{ng} / \mathrm{ml}$. In addition, the magnitude of the increase in HR by IGF $_{1}$ was similar to that produced by $400 \mathrm{ng} / \mathrm{ml}$ of insulin. Thus, concentrations of $\mathrm{IGF}_{1}$ as low as $10 \mathrm{ng} / \mathrm{ml}$ produced increases in cellular LPL that paralleled the effects of pharmacologic concentrations of insulin.

\section{Discussion}

The cellular regulation of adipose tissue LPL has been difficult to characterize, largely because of the lack of a good in vitro model. Although LPL has previously been studied in shortterm experiments with rat adipocytes, LPL has never been measured in isolated human adipocytes. Hence, an in vitro system of human cells is needed where the effects of insulin and other potential regulators of LPL can be measured in a controlled environment at the cellular level. Because attempts to use human adipocyte precursors to study LPL have been unsuccessful (25), we have focused our attention on primary cultures of mature adipocytes.

In this study, isolated human adipocytes were obtained from a collagenase digestion of omental adipose tissue. When cultured in Medium 199, these cells remained viable for up to $72 \mathrm{~h}$ after preparation, as evidenced by constant cell number, cell size, and low trypan blue uptake. In addition, these cells demonstrated constant ${ }^{125} \mathrm{I}$-insulin binding and a chloroquinemediated increase in cell-associated radioactivity. Chloroquine

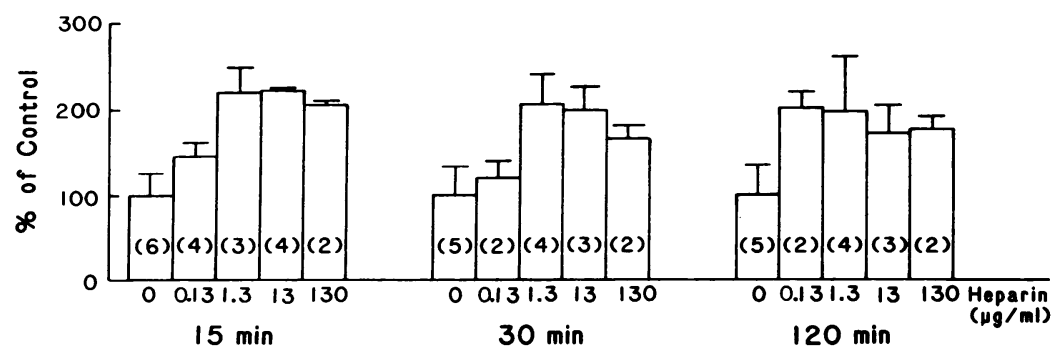

Figure 7. Heparin dose response. After adipocytes were cultured for $24 \mathrm{~h}$, various concentrations of heparin were added to the medium and cells were incubated for the indicated times. The LPL released by each concentration of heparin is expressed as the percentage of control cells (no heparin added, mean \pm SE). 


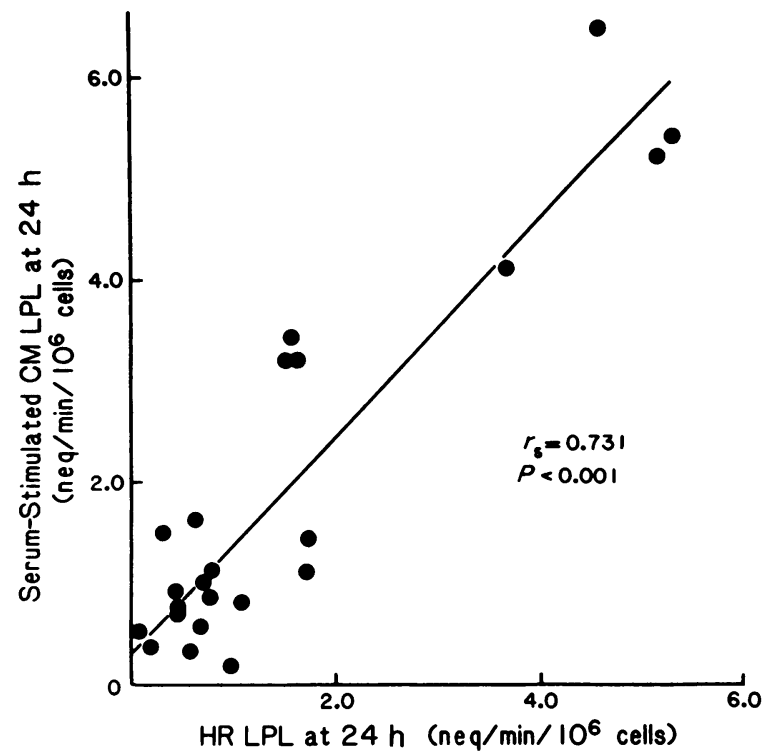

Figure 8. Relationship between HR and CM. Cells from 23 subjects were cultured for $24 \mathrm{~h}$ in the presence and absence of $10 \%$ fetal bovine serum and then assayed for LPL. CM activity in the presence of serum is plotted as a function of HR in the absence of serum.

has previously been shown to block intracellular insulin degradation, resulting in an increase in cell-associated ${ }^{125} \mathrm{I}$-insulin (21). Because internalization of insulin is an energy-dependent process (21), the presence of a chloroquine effect provides strong evidence of functional viability and suggests that these

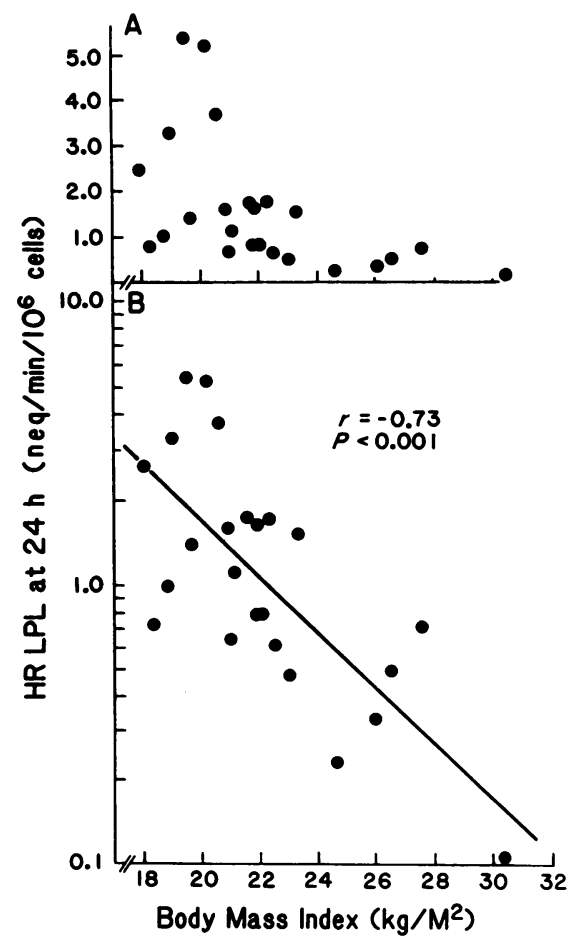

Figure 9. Effects of body mass index on LPL. (A) HR LPL activity in adipocytes cultured for $24 \mathrm{~h}$ in Medium 199 is plotted as a function of subject's body mass index (weight/height $\left.{ }^{2}\right)$. (B) Logarithmic transformation of data in $A$.

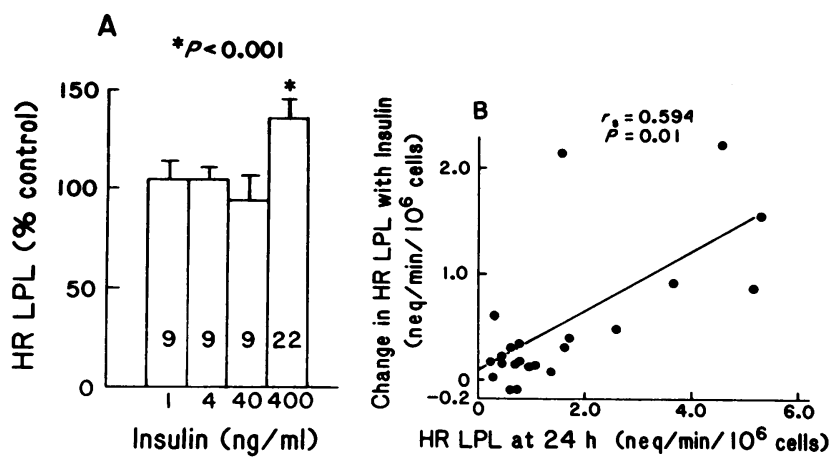

Figure 10. Effect of insulin on HR LPL. (A) Adipocytes were cultured in Medium 199 for $24 \mathrm{~h}$ in the absence and presence of insulin in the indicated concentrations. HR LPL activity is shown for each insulin concentration and expressed as percentage of control HR. $(B)$ Increasing insulin effect with increasing basal activity. The change in $\mathrm{HR}$ in response to insulin $400 \mathrm{ng} / \mathrm{ml}$ is plotted as a function of control HR at $24 \mathrm{~h}$.

cells retain the ability to bind, internalize, and degrade insulin. Insulin binding in freshly prepared human adipocytes from subcutaneous and omental fat has been previously reported (32-35) and similar degrees of cell-associated ${ }^{125} \mathrm{I}$-insulin were demonstrated. In the present study, insulin binding remained constant, although the magnitude of the chloroquine effect was greater in cultured cells than in freshly prepared cells. This latter observation is consistent with a previous study (34), which determined that freshly prepared human adipocytes did not degrade ${ }^{125}$ I-insulin. In addition, Marshall (18) observed an increased chloroquine effect in isolated rat adipocytes between 12 and $48 \mathrm{~h}$ in culture. Thus, this increasing chloroquine effect may be due to recovery of normal cell function in culture after dissipation of residual effects of the isolation procedure. Alternatively, the culture medium environment may serve to improve coupling among insulin binding, internalization, and degradation.

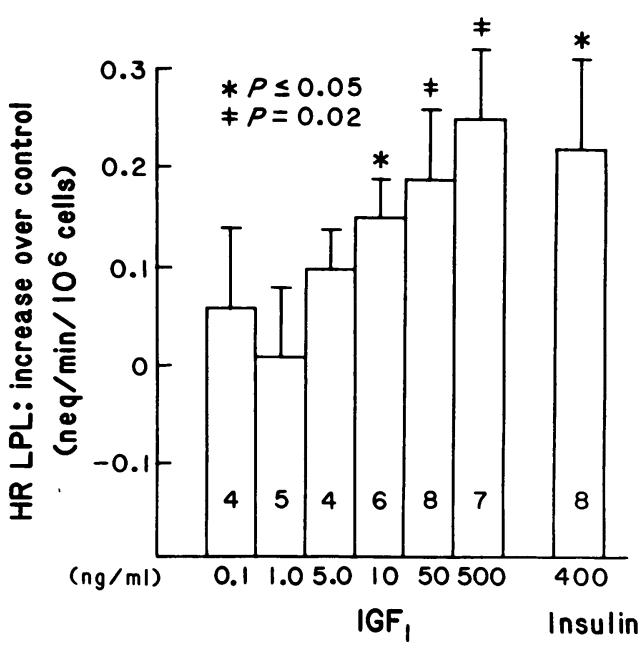

Figure 11. Effect of IGF, on HR LPL. Adipocytes were cultured overnight in Medium 199 containing the indicated concentrations of IGF $_{1}$. The effect of insulin $(400 \mathrm{ng} / \mathrm{ml})$ was assessed in parallel adipocyte cultures. Data are expressed as the increase in HR activity over the control cultures (mean \pm SE). 
Soon after preparation, LPL was measurable as CM and in the cells as HR, and as EXT after the release by heparin. CM was markedly stimulated by the presence of $10 \%$ whole and dialyzed fetal bovine serum. This is in agreement with observations in rat adipocytes (36-38) in which LPL secretion was stimulated by a factor in serum with a molecular weight of $>100,000$ (38). The effect of serum in the present study may have been not to stimulate secretion but to stabilize LPL. The half-life of CM LPL in the presence of serum at $37^{\circ} \mathrm{C}$ was $66 \mathrm{~min}$, and the addition of serum to $\mathrm{CM}$ from control cultures produced no increase in LPL activity. Hence, LPL may be spontaneously secreted from adipocytes but then inactivated virtually instantaneously in the absence of serum. The addition of serum to HR did not prolong its half-life significantly. However, the HR enzyme is already stabilized by heparin, and serum may not stabilize LPL further. Thus, these data cannot definitively distinguish between a stabilization of LPL by serum and a direct stimulation of secretion. The longer half-life of HR is consistent with the tendency of heparin to stabilize LPL in nonpurified preparations (39).

The release of enzyme activity by heparin occurred quickly and was dose dependent. After $15 \mathrm{~min}$ of heparin exposure, LPL activity that was released reached a plateau. Because the HR enzyme has a finite half-life of $135 \mathrm{~min}$, this plateau of activity probably represents a steady state of continuous new enzyme release along with inactivation of enzyme already released. In addition, HR activity was not depleted by a prior maximal release of enzyme activity by heparin. Together, these data suggest that heparin causes the release of LPL from a pool of activity that can be rapidly replenished from cellular stores. This replenishment may result from new enzyme synthesis or may be due to the transfer of activity from one cellular site to another.

The ability of heparin to release LPL in vivo (39), from adipose tissue pieces (40-42), and from isolated cells $(17,37$, $40,43)$ has long been recognized. Previous studies $(2,17,40$, $42,44)$ have also demonstrated that heparin-releasable LPL represents a source of activity that is responsive to regulation by various agents. In the present study, HR at $24 \mathrm{~h}$, but not EXT, correlated strongly with secreted (CM) activity in response to serum. Since LPL must be secreted from adipocytes in order to become localized to the capillary endothelium, HR represents an important functional and regulatable component of cellular LPL activity and may be a key determinant of the LPL that is available in vivo for triglyceride hydrolysis.

HR activity at $24 \mathrm{~h}$ was inversely correlated with the subjects' body mass index. LPL in whole adipose tissue, when expressed per $10^{6}$ cells, has previously been shown to be directly related to degree of obesity $(3,7)$. In addition, the study by Schwartz and Brunzell (7) demonstrated that LPL activity in subcutaneous adipose tissue from obese subjects increased in response to weight loss. The subjects in the present study were in general of near-normal body weight, and LPL was measured in isolated cells from omental adipose tissue in culture, making comparisons with other studies difficult. Together, however, the data from whole adipose tissue and from isolated cells may be reconciled by the speculation that with increasing adiposity, a mobilization of LPL from cellular to extracellular stores may occur. Thus, isolated adipocytes would be expected to have less cellular LPL with increasing body weight as demonstrated in the present study, whereas whole adipose tissue would display more total LPL activity, as shown by others $(3,7)$.

Insulin has long been considered to be a probable hormonal regulator of LPL, although the effects of this hormone have varied and depended upon the system examined. Studies in rats have demonstrated an increase in whole adipose tissue LPL in the fed versus the fasted state $(36,40,45)$. This increase in LPL, however, was found in whole fat pads, but only inconsistently in simultaneously isolated rat adipocytes. Whether this increase in whole tissue LPL was due to glucose, insulin, or some other component of the fed state could not be determined. Studies in 3T3-L1 cells have suggested that there is an effect of insulin on both LPL synthesis and secretion $(44,46)$, whereas other studies in rat adipose tissue or cells have not been able to distinguish between the two effects or have suggested that the predominant effect is on synthesis (4749). An effect of insulin added in vitro has only recently been demonstrated in isolated rat adipocytes (17). This increase is predominantly on cellular LPL and is inhibited by cycloheximide, suggesting a dependence on protein synthesis.

Although insulin appears to stimulate LPL in animals, the role of insulin in the regulation of human LPL is less clear (50). Decreases in LPL in fat biopsies have been observed when insulin levels are low, as in starvation (51), during hypocaloric feeding $(41,52)$, and in poorly controlled insulindependent diabetes (2). However, wide variations in basal activity create substantial overlap between controls and uncontrolled diabetics (3). Studies in normal humans have also been difficult to interpret. Feeding studies have shown inconsistent increases in LPL activity between 1 and $6 \mathrm{~h}$ after feeding (3, 53). Using the euglycemic clamp technique, Sadur and Eckel (42) have shown a stimulatory effect on insulin on whole adipose tissue LPL in normal subjects. In contrast to the results of feeding studies, however, this effect required $6 \mathrm{~h}$ of relative hyperinsulinemia $(\sim 70 \mu \mathrm{U} / \mathrm{ml})$ and a simultaneous glucose infusion. Furthermore, attempts to demonstrate an effect of insulin added to whole human adipose tissue in vitro were unsuccessful (54).

In the present study, insulin was added to primary cultures of isolated human adipocytes over a broad range of concentrations. Only at $400 \mathrm{ng} / \mathrm{ml}$, a pharmacologic concentration, was there an increase in cellular (predominantly HR) LPL activity. This effect was consistently seen, although the magnitude of this high-dose insulin effect on HR varied directly with control HR. Physiologic concentrations of insulin had no consistent effect on LPL, regardless of the control activity, and $400 \mathrm{ng} /$ $\mathrm{ml}$ of insulin had no effect in the presence of $10 \%$ fetal bovine serum. Because high insulin concentrations have been shown to cross-react with $\operatorname{IGF}_{1}$ receptors in many systems $(30,31)$, the effect of a spectrum of concentrations of $I_{G} F_{1}$ was compared with the effect of $400 \mathrm{ng} / \mathrm{ml}$ of insulin. IGF 1 elicited a dosedependent increase in HR that was statistically significant at a concentration as low as $10 \mathrm{ng} / \mathrm{ml}$. In addition, the magnitude of the increase in $\mathrm{HR}$ with $\mathrm{IGF}_{1}$ was similar to that produced by $400 \mathrm{ng} / \mathrm{ml}$ of insulin. This suggests that the effect of this high insulin concentration on LPL may actually be mediated through low affinity IGF $_{1}$ receptor binding. Consistent with this hypothesis is the lack of an additive effect when insulin is added to cells cultured in $10 \%$ serum. Although the increase in $\mathrm{HR}$ by serum is probably mediated by a number of factors, the IGF $_{1}$ in serum would be expected to contribute to this 
effect and thus prevent any further action of insulin on IGF receptors.

The response of human adipocytes to insulin differs from that observed by us in isolated rat adipocytes (17) and in vivo during the euglycemic clamp (42). During a euglycemic clamp, however, the insulin infusion is accompanied by an elevated glucose disposal rate, which may have independent effects on LPL. Furthermore, in rat adipocytes cellular LPL continues to increase with insulin concentrations well above the physiologic range, suggesting that there may be a role for $\mathrm{IGF}_{1}$, as well as for insulin, in these cells.

Although the concentration of insulin required to stimulate LPL was clearly pharmacologic, it is difficult to estimate what concentration of $\mathrm{IGF}_{1}$ in vitro truly reflects in vivo physiology. Various studies have measured plasma IGF $_{1}$ concentrations in humans and reported concentrations as low at $24 \mathrm{ng} / \mathrm{ml}$ in growth hormone-deficient subjects (55) and as high as $722 \mathrm{ng} /$ $\mathrm{ml}$ in diabetics with proliferative retinopathy (56). Further complicating the matter, however, is the degree to which IGF $_{1}$ is protein bound. Several independent studies failed to detect any free $\operatorname{IGF}_{1}$ in whole serum $(57,58)$. In addition, it is not known whether biologically active $I_{\text {GF }}$ is the free or the protein-bound moiety (59). Thus, the concentrations of IGF $_{1}$ in cell culture that properly reflect physiological concentrations cannot be stated with certainty. However, the concentrations that stimulate LPL in this study closely parallel the concentrations that effectively compete for $\mathrm{IGF}_{1}$ binding in other systems $(31,60)$.

As the structure and function of insulin, $\mathrm{IGF}_{1}$, and insulinlike growth factor 2 have become better characterized, two types of receptor-mediated, anabolic processes have been defined. Rapid cellular responses, such as glucose transport, occur via the insulin receptor, whereas slower, growth-promoting responses are mediated through the insulin-like growth factor receptors $(30,61)$. Previous studies have demonstrated specific IGF $_{1}$ binding to rat adipocytes as well as a stimulation of glucose transport and an inhibition of lipolysis (60). These biological effects, however, are acute responses and indeed were abolished by the removal of the insulin receptors by a brief exposure to trypsin (62). This led to the conclusion that the acute biological effects of IGF $_{1}$ and adipocytes are mediated through cross-reactivity with the insulin receptor $(61,62)$. However, because adipocytes could not previously be sustained for more than a few hours in vitro, it was not possible to measure any long-term biological effects of IGF $_{1}$. Because of the demonstrated viability of the cultured adipocytes described herein, this system is better able to study IGF $_{1}$ mediated processes. Our data, which demonstrate an effect on LPL by insulin at $400 \mathrm{ng} / \mathrm{ml}$ and by $I_{1} F_{1}$ at $10 \mathrm{ng} / \mathrm{ml}$, represent a response characteristic of one mediated through an IGF receptor. In addition, preliminary data from our lab, using the IGF analogue described in Methods, confirm that both cultured rat and human adipocytes specifically bind IGF $_{1}$ (Kern, P. A., D. Graves, J. J. Van Wyk, and R. H. Eckel, unpublished observations). Whether or not IGF $_{1}$ plays an important role in LPL regulation in vivo remains to be determined.

Together, these studies demonstrate that isolated human adipocytes can survive for several days in a tissue culture environment and produce and secrete LPL. Heparin causes the release of LPL activity from a rapidly replenishable pool of cellular activity (HR) which correlates strongly with the secretory response to serum. In addition, HR is regulated by such factors as body mass index and serum. Insulin in a high concentration and IGF $_{1}$ at lower concentrations both stimulate HR to a similar degree, indicating that the effect of insulin on LPL in isolated human adipocytes could occur via crossreactivity with $I_{\text {GF }}$ receptors. This method for culturing adipocytes should prove useful for further studies on the regulation of LPL and for investigations into other aspects of human adipocyte cell biology.

\section{Acknowledgments}

We wish to thank the many surgeons in the Department of Surgery and Obstetrics and Gynecology at The University of Colorado and at Rose Memorial Hospital (Denver) for their cooperation in obtaining omental adipose tissue, and Drs. Mary Peters and Noel Stebbing of AMGen Development, Inc. for generously providing the IGF 1 analogue. We also thank Sally Frye for her secretarial assistance.

This work was supported by grant AM 26356 from the National Institutes of Arthritis, Diabetes, Digestive and Kidney Diseases of the National Institutes of Health; grant 80R055 from the Juvenile Diabetes Foundation; the Gail Patrick Velde Feasibility Award from the American Diabetes Association; Research Fellowships 2-5-31990 and 2-5-32204 from the Colorado Heart Association; and grant AM 07116-01 from the National Institutes of Health.

\section{References}

1. Robinson, D. S. 1970. The function of plasma triglycerides in fatty acid transport. In Comprehensive Biochemistry. Vol. 18. M. Florkin and E. M. Stotz, editors. Elsevier Nederland, Amsterdam. 51116.

2. Taskinen, M.-R., and E. A. Nikkila. 1979. Lipoprotein lipase activity of adipose tissue and skeletal muscle in insulin-deficient human diabetes. Relation to high-density and very-low-density lipoproteins and response to treatment. Diabetologia. 17:351-356.

3. Pykalisto, O. J., P. H. Smith, and J. D. Brunzell. 1975. Determinants of human adipose tissue lipoprotein lipase. Effect of diabetes and obesity on basal and diet-induced activity. J. Clin. Invest. 56:1108-1117.

4. Goldberg, A., D. J. Sherrard, and J. D. Brunzell. 1978. Adipose tissue lipoprotein lipase in chronic hemodialysis. Role of plasma triglyceride metabolism. J. Clin. Endocrinol. Metab. 47:1173-1182.

5. Valdemarsson, S., P. Hedner, and P. Nilsson-Ehle. 1982. Reversal of decreased hepatic lipase and lipoprotein lipase activities after treatment of hypothyroidism. Eur. J. Clin. Invest. 12:423-428.

6. Pykalisto, O. J., A. P. Goldberg, and J. D. Brunzell. 1976. Reversal of decreased human adipose tissue lipoprotein lipase and hypertriglyceridemia after treatment of hypothyroidism. J. Clin. Endocrinol. Metab. 43:591-600.

7. Schwartz, R. S., and J. D. Brunzell. 1981. Increase of adipose tissue lipoprotein lipase activity with weight loss. J. Clin. Invest. 67:1425-1430.

8. Taskinen, M.-R., and E. A. Nikkila. 1981. High density lipoprotein subfractions in relation to lipoprotein lipase activity of tissue in man. Evidence for reciprocal regulation of $\mathrm{HDL}_{2}$ and $\mathrm{HDL}_{3}$ levels by lipoprotein lipase. Clin. Chim. Acta. 112:325-332.

9. Eder, H. A., and L. I. Gidez. 1982. The clinical significance of the plasma high density lipoproteins. Med. Clin. N. Am. 66:431-440.

10. Nilsson-Ehle, P., A. S. Garfinkel, and M. C. Schotz. 1980. Lipolytic enzymes and plasma lipoprotein metabolism. Annu. Rev. Biochem. 49:667-693.

11. Eckel, R. H., W. Y. Fujimoto, and J. D. Brunzell. 1977. Development of lipoprotein lipase in cultured 3T3-L1 cells. Biochem. Biophys. Res. Commun. 78:288-293. 
12. Negrel, R., P. Grimaldi, and G. Ailhaud. 1978. Establishment of preadipocyte clonal line from epididymal fat pad of ob/ob mouse that responds to insulin and lipolytic hormones. Proc. Natl. Acad. Sci. USA. 75:6054-6058.

13. Rothblat, G. H., and F. D. DeMartinis. 1977. Release of lipoprotein lipase from rat adipose tissue cells grown in culture. Biochem. Biophys. Res. Commun. 78:45-50.

14. Eckel, R. H., W. Y. Fujimoto, and J. D. Brunzell. 1981. Effects of in vitro lifespan of 3T3-L1 cells on hormonal responsiveness of lipoprotein lipase activity. Int. J. Obesity. 5:571-578.

15. Hausman, G. J., D. R. Campion, and R. J. Martin. 1980. Search for the adipocyte precursor cell and factors that promote its differentiation. J. Lipid Res. 21:657-670.

16. Cunningham, V. J., and D. S. Robinson. 1969. Clearing-factor lipase in adipose tissue. Distinction of different states of the enzyme and the possible role of the fat cell in the maintenance of tissue activity. Biochem. J. 112:203-209.

17. Eckel, R. H., J. E. Prasad, P. A. Kern, and S. Marshall. 1984. Insulin regulation of lipoprotein lipase in cultured isolated rat adipocytes. Endocrinology. 114:1665-1671.

18. Marshall, S. 1983. Kinetics of insulin receptor biosynthesis and membrane insertion: relationship to cellular function. Diabetes. 32:319325.

19. Metropolitan Life Insurance Company. 1959. New weight standards for men and women. Statistical Bulletin. 40:1-4.

20. Rodbell, M. 1964. Metabolism of isolated fat cells. I. Effects of hormones on glucose metabolism and lipolysis. J. Biol. Chem. 239:375380.

21. Marshall, S., and J. M. Olefsky. 1979. Effects of lysosomotropic agents on insulin interactions with adipocytes. Evidence of a lysosomal pathway for insulin processing and degradation. J. Biol. Chem. 254:10153-10160.

22. DiGirolamo, M., S. Medlinger, and J. W. Fertig. 1977. A simple method to determine fat cell size and number in four mammalian species. Am. J. Physiol. 221:850-858.

23. Hirsch, J., and E. Gallian. 1968. Methods for the determination of adipose cell size in man and animals. J. Lipid Res. 9:110-119.

24. Eckel, R. H., and W. Y. Fujimoto. 1981. Quantitation of cell death in human fibroblasts by measuring the loss of $\left[{ }^{14} \mathrm{C}\right]$ thymidine from prelabeled cell monolayers. Anal. Biochem. 114:118-124.

25. Kern, P. A., and R. H. Eckel. 1984. Absence of lipoprotein lipase in cultured human adipose stromal cells. Arteriosclerosis. 4:232237.

26. Chait, A., P.-H. Iverius, and J. D. Brunzell. 1982. Lipoprotein lipase secretion by human monocyte-derived macrophages. J. Clin. Invest. 69:490-493.

27. Belfrage, P., and M. Vaughn. 1969. Simple liquid-liquid partition system for isolation of labeled oleic acid from mixture with glycerides. J. Lipid Res. 10:341-344.

28. Rinderknecht, E., and R. E. Humbel. 1976. Polypeptides with NSILA and growth promoting activity in human serum: isolation, chemical characterization, and some biological properties of forms I and II. Proc. Natl. Acad. Sci. USA. 73:2365-2369.

29. Reismann, D., D. Schalch, C. Emler, D. Dills, C. Sessions, D. Snitman, M. Peters, E. Lau, and R. Humbel. 1984. Recombinant DNA-synthesized insulin-like growth factor I/somatomedin C (IGF-I/ $\mathrm{SmC}$ ) analog: immunochemical, receptor binding, and biological properties. Clin. Res. 32:406A. (Abstr.)

30. Czech, M. P. 1982. Structural and functional homologies in the receptors for insulin and the insulin-like growth factors. Cell. 31:810.

31. Nissley, S. P., and M. M. Rechler. 1984. Somatomedin/insulinlike growth factor tissue receptors. Clin. Endocrinol. Metab. 13:43-67.

32. Olefsky, J. M., P. Jen, and G. M. Reaven. 1974. Insulin binding to isolated human adipocytes. Diabetes. 23:565-571.

33. Olefsky, J. M. 1981. Insulin resistance and insulin action: an in vitro and in vivo perspective. Diabetes. 30:148-161.
34. Pedersen, I., E. Hjollund, H. Beck-Neilsen, H. O. Lindskov, O. Sonne, and J. Gliemann. 1981. Insulin receptor binding and receptormediated insulin degradation in human adipocytes. Diabetologia. 20:636-641.

35. Bolinder, J., L. Kager, J. Ostman, and P. Arner. 1983. Differences at the receptor and postreceptor levels between human omental and subcutaneous adipose tissue in the action of insulin on lipolysis. Diabetes. 32:117-123.

36. Nilsson-Ehle, P., A. S. Garfinkel, and M. C. Schotz. 1976. Intra- and extracellular forms of lipoprotein lipase in adipose tissue. Biochem. Biophys. Acta. 431:147-156.

37. Stewart, J. E., and M. C. Schotz. 1974. Release of lipoprotein lipase activity from isolated fat cells. II. Effects of heparin. J. Biol. Chem. 249:904-907.

38. Stewart, J. E., and M. C. Schotz. 1973. Stimulation of release of lipoprotein lipase activity from isolated fat cells by rat serum. Nature New Biol. 244:250-251.

39. Olivacrona, T., G. Bengtsson, S.-E. Marklund, U. Lindhal, and M. Hook. 1977. Heparin-lipoprotein lipase interactions. Fed. Proc. 36:60-65.

40. Pokrajac, N., W. J. Lossow, and I. L. Chaikoff. 1967. The effect of nutritional state on lipoprotein lipase activity in isolated rat adipose tissue cells. Biochim. Biophys. Acta. 139:123-132.

41. Taskinen, M.-R., and E. A. Nikkila. 1981. Lipoprotein lipase of adipose tissue and skeletal muscle in human obesity: response to glucose and to semistarvation. Metab. Clin. Exp. 30:810-817.

42. Sadur, C. N., and R. H. Eckel. 1982. Insulin stimulation of adipose tissue lipoprotein lipase. Use of the euglycemic clamp technique. J. Clin. Invest. 69:1119-1125.

43. Kornhauser, D. M., and M. Vaughn. 1975. Release of lipoprotein lipase from fat cells in vitro. Biochim. Biophys. Acta. 380:97-105.

44. Eckel, R. H., W. Y. Fujimoto, and J. D. Brunzell. 1978. Insulin regulation of lipoprotein lipase in cultured 3T3-L1 cells. Biochem. Biophys. Res. Commun. 84:1069-1075.

45. Spencer, J. M., A. Hutchinson, and D. S. Robinson. 1978. The effect of nutritional state on the lipoprotein lipase activity of isolated fat cells. Biochim. Biophys. Acta. 530:375-384.

46. Spooner, P. M., S. S. Chernick, M. D. Garrison, and R. O. Scow. 1979. Insulin regulation of lipoprotein lipase activity and release of 3T3-L1 adipocytes. Separation and dependence of hormonal effects on hexose metabolism and synthesis of RNA and protein. J. Biol. Chem. 254:10021-10029.

47. Ashby, P., D. P. Bennett, I. M. Spencer, and D. S. Robinson. 1978. Post-translational regulation of lipoprotein lipase activity in adipose tissue. Biochem. J. 176:865-872.

48. Garfinkel, A. S., P. Nilsson-Ehle, and M. C. Schotz. 1976. Regulation of lipoprotein lipase induction by insulin. Biochim. Biophys. Acta. 424:264-273.

49. Parkin, S. M., K. Walker, P. Ashby, and D. S. Robinson. 1980. Effects of glucose and insulin on the activation of lipoprotein lipase and on protein synthesis in rat adipose tissue. Biochem. J. 188:193199.

50. Brunzell, J. D., R. S. Schwartz, R. H. Eckel, and A. P. Goldberg. 1981. Insulin and adipose tissue lipoprotein lipase in humans. Int. J. Obesity. 5:685-694.

51. Persson, B., B. Hood, and G. Angervall. 1970. Effects of prolonged fast on lipoprotein lipase activity eluted from human adipose tissue. Acta. Med. Scand. 188:225-230.

52. Taskinen, M.-R., and E. A. Nikkila. 1977. Effects of caloric restriction on lipid metabolism in man: changes of tissue lipoprotein lipase activities and of serum lipoproteins. Atherosclerosis. 32:289299.

53. Nilsson-Ehle, P., S. Carlstrom, and P. Belfrage. 1975. Rapid effects on lipoprotein lipase activity in adipose tissue of humans after carbohydrate and lipid intake. Time course and relation of plasma glycerol, triglyceride, and insulin levels. Scand. J. Lab. Invest. 35:373378. 
54. Elkeles, R. S. 1974. Lipoprotein lipase in human adipose tissue. Clin. Sci. Mol. Med. 46:753-762.

55. Merimee, T. J., J. Zapf, and E. R. Froesch. 1981. Dwarfism in the pygmy. An isolated deficiency of insulin-like growth factor I. $N$. Engl. J. Med. 305:965-968.

56. Merimee, T. J., J. Zapf, and E. R. Froesch. 1983. Insulin-like growth factors. Studies in diabetics with and without retinopathy. $N$. Engl. J. Med. 309:527-530.

57. Chatelain, P. G., J. J. Vay Wyk, K. C. Copeland, S. L. Blethen, and L. E. Underwood. 1983. Effect of in vitro action of serum proteases or exposure to acid on measurable immunoreactive somatomedin-C in serum. J. Clin. Endocrinol. Metab. 56:376-383.

58. Daughaday, W. H., A. P. Ward, A. C. Goldberg, B. Trivedi, and M. Kapadia. 1982. Characterization of somatomedin binding in human serum by ultracentrifugation and gel filtration. J. Clin. Endocrinol. Metab. 55:916-921.

59. Hintz, R. L. 1984. Plasma forms of somatomedin and the binding protein phenomenon. Clin. Endocrinol. Metab. 13:31-42.

60. Zapf, J., E. Schoenle, and E. R. Froesch. 1978. Insulin-like growth factors I and II. Some biological actions and receptor binding characteristics of two purified constituents of nonsuppressible insulinlike activity of human serum. Eur. J. Biochem. 87:285-296.

61. Zapf, J., Ch. Schmid, and E. R. Froesch. 1984. Biological and immunological properties of insulin-like growth factors (IGF) I and II. Clin. Endocrinol. Metab. 13:3-30.

62. Zapf, J., E. Schoenle, M. Waldvogel, I. Sand, and E. R. Froesch. 1981. Effect of trypsin treatment of rat adipocytes on biological effect and binding of insulin and insulin-like growth factors. Eur. $J$. Biochem. 113:605-609. 